\title{
STUDI MORFOLOGI BULIR DAN MAPPING KONTAMINASI PADA TANAH VULKANIK UNTUK MENGENALI PENGARUH PESTISIDA MENGGUNAKAN SCANNING ELECTRON MICROSCOPE (SEM)
}

\author{
Eleonora Agustine \\ Departemen Geofisika Fakultas Matematika dan Ilmu Pengetahuan Alam, \\ Universitas Padjadjaran, Sumedang 45363, Indonesia \\ Email: leo@geophys.unpad.ac.id
}

\begin{abstract}
Abstrak
Kajian penggunaan pestisida pada lahan pertanian perlu dilakukan karena penggunaannya yang terus menerus dalam jangka waktu yang lama akan berakibat pada masalah kesehatan masyarakat dan lingkungan. Pada paper ini kajian dilakukan di tanah vulkanik di PTPN VIII Bukit Tunggul Jawa Barat. Untuk mengamati perubahan yang terjadi pada tanah vulkanik akibat pengaruh pestisida pada penelitian ini akan dilakukan kajian mineralogi dan morfologi bulir magnetic menggunakan Scanning Electron Microscope (SEM). Conto diambil pada outcrop sebanyak 60 contoh dari dua lapisan yang berbeda sifat fisiknya. Conto dibagi menjadi 3 grup berbeda untuk diamati perubahannya setiap 3 bulan. Grup pertama conto standar (tanpa penambahan pestisida), grup ke dua diberi pestisida dengan variasi $5 \mathrm{ml}$ pestisida ditambah aquabidest $45 \mathrm{ml}, 10 \mathrm{ml}$ pestisida dan $40 \mathrm{ml}$ aquabidest sampai $50 \mathrm{ml}$ murni pestiseda. Masing-masing contoh diberi 5 tetes. Grup kedua disimpan selama 3 bulan dan diamati hasilnya, demikian pula grup ke tiga disimpan 6 bulan. Dari hasil pengamatan bulan terlihat bahwa pengaruh pestisda merusak bulir magnetik yang ada, dan membuat bulir menjadi lebih halus. Dan proses penghalusan bulir magnetik ini diduga akibat disolusi atau oksidasi.
\end{abstract}

Kata-kata kunci: Pestisida, tanah volkanik, morfologi bulir

\begin{abstract}
Study of the use of pesticides on agricultural land necessary for continuous use in the long term will result in environmental and public health problems. In this paper, a study carried out in volcanic soil in PTPN VIII West Java Bukit stumps. To observe the changes that occur in volcanic soils due to the effect of pesticides on the study will examine the mineralogy and morphology of magnetic grains using a Scanning Electron Microscope (SEM). Outcrop samples were taken on as many as 60 instances of two layers of different physical properties. Conto is divided into 3 different groups to observe the changes every three months. The first group of samples, standard (without the addition of pesticides), the second group was given pesticide with a variety of pesticides plus $5 \mathrm{ml}$ aquabidest $45 \mathrm{ml}, 10 \mathrm{ml}$ and $40 \mathrm{ml}$ pesticide aquabidest to $50 \mathrm{ml}$ of pure pestiseda. Each sample was given five drops. The second group is stored for 3 months and observed the results, as well as a group to three stored 6 months. From the observation moon is seen that the influence of the magnetic grains pestisda existing damage, and make the grain becomes finer. And the process of refining grains of magnetic allegedly due to dissolution or oxidation.
\end{abstract}

Keywords: Pesticides, volcanic soil, grain morphology 


\section{PENDAHULUAN}

Pestisida dipergunakan petani sebagai salah satu cara untuk meningkatkan produksi pertanian. Penggunaan ini bertujuan untuk membasmi hama dan penyakit tanaman. Akibat penggunaannya dalam waktu yang lama dan terus menerus terjadi akumulasi residu di dalam tanah dan lingkungan [1]. Beberapa pestisida mempunyai daya tahan yang lama di tanah dengan waktu paruhnya adalah 20 tahun [1]. Residu pestisida ini memberikan dampak negative pada lingkungan dan kesehatan masyarakat seperti masuknya residu kedalam rantai makanan mengakibatkan penyakit kulit dan kanker [2] Batas toleransi maximum residue limits (MRLs) untuk pestisida dari beberapa negara antara lain Australian adalah $0.20 \mathrm{mg} / \mathrm{kg}$ (1 part in 5 million) dan United States $0.3 \mathrm{mg} / \mathrm{kg}$. DDT MRLs Untuk DDT MRLs negara Australia, Jepang dan USA adalah $4 \mathrm{mg} / \mathrm{kg}$, EU dan Canada 1 $\mathrm{mg} / \mathrm{kg}[2]$.

Untuk mengenali kontaminasi residu pestida pada tanah akan digunakan metoda kemagnetan batuan. Metoda ini sudah banyak digunakan untuk mengkaji lingkungan (Thompson, dkk, 1989) [3] antara lain mencermati masalah pencemaran lingkungan untuk identifikasi lokasi polutan, monitoring kualitas lingkungan dan menentukan sumber polutan [4-5]. Metoda kemagnetan batuan dibandingkan dengan metoda analisis selama ini relative lebih murah, cepat dan non destruktif [4-5]. Sehingga metoda ini sudah banyak juga digunakan untuk kajian soil.

Selain metoda magnetic, sampel akan dianalisis menggunakan Scanning Electron Microscopy (SEM) yang akan membantu identifikasi mineral magnetic secara lebih detil. SEM akan memperlihatkan karakteristik sampel berupa ukuran, bentuk dan permukaan bulir serta komposisi kimiawinya. Kajian visualisasi ini akan sangat mendukung kajian magnetik [6].

\section{DESKRIPSI DAERAH PENELITIAN DAN METODA SAMPLING}

Penelitian dilakukan di Bukit Tunggul tempat penaman Kina ( $6^{\circ} 50^{\prime} 5.1948^{\prime \prime} \mathrm{S} ; 107^{\circ} 43^{\prime} 42.1148^{\prime \prime}$ E, elevasi 1499 masl) berjarak sekitar $25 \mathrm{~km}$ dari Bandung. Posisi pusat perkebunan adalah $15 \mathrm{~km}$ dari Lembang dan $12 \mathrm{~km}$ dari utara Bandung. Lembang merupakan pusat perkebunan di provinsi Jawa Barat karena kesuburan tanah vulkaniknya. Lembang terletak pada kaki gunung Tangkubanperahu, yang merupakan salah satu pengunungan yang aktif dan mempunyai sejarah letusan yang panjang.

Sampel tanah diambil dari outcrop yang mempunyai tinggi sekitar $3 \mathrm{~m}$. Horizon tanah pada daerah sampling terlihat kasat mata mempunyai warna dan tertur yang berbeda. Secara umum horizon tanah tanah terbagi menjadi 3 bagian yang dikontrol oleh aktivitas vulkanik. Lapisan Lapisan 1 atau horizon 1 (A1) (ketebalan sekitar $80 \mathrm{~cm}$ ) didominasi lapisan kemerahan ciri lapisan organik, Horizon 2 (A2), (ketebalan sekitar $63 \mathrm{~cm}$ ) berwarna kehitaman diperkirakan sebagai deposit ash-flow. Pada outcrop conto diambil per $10 \mathrm{~cm}$, conto ditempatkan pada holder silinder dengan diameter $2.5 \mathrm{~cm}$ in diameter dan tinggi $2.2 \mathrm{~cm}$. Pada studi ini ada 30 conto yang diamati.

Sampel dibagi untuk monitoring 3 bulanan kemudian masing-masing diberikan variasi pestida $5 \mathrm{ml}, 10 \mathrm{ml}$, $15 \mathrm{ml}, 20 \mathrm{ml}, 25 \mathrm{ml}, 30 \mathrm{ml}, 35 \mathrm{ml}, 40 \mathrm{ml}, 45 \mathrm{ml}, 50 \mathrm{ml}$. Sampel akan diamati setiap 3 bulan untuk melihat pengaruhnya pada volcanic soil.

\section{METODA SCANNING ELECTRON MICROSCOPE (SEM)}

Sampel akan dianalisis menggunakan Scanning Electron Microscopy (SEM) untuk mendapatkan informasi tambahan mengenai bentuk bulir, ukuran dan morfologi bulir serta unsur kimia yang menyertainya. SEM yang digunakan adalah Jeol JSM-6360LA yang dilengkapi dengan Backscattering Electron (BSE) dan Energy Dispersive X-Ray (EDX). BSE dipergunakan untuk mendapatkan visualisasi bentuk bulir khususnya iron oxide, EDX dipergunakan untuk mendapatkan analisis unsur kimawinya [6]. 


\section{HASIL DAN DISKUSI}

Pada beberapa kajian top soil yang mengalami kontaminasi nilai suseptibilitas magnetik pada tanah akan membesar apabila: (1) ukuran bulirnya kecil yaitu lebih kecil dari 50nm, (2) proses kimia seperti reduksi-oksidasi (3) proses biogeokimia dan translokasi hal ini dikatakan oleh: Schibler dkk. (2002); Fialova. dkk (2006): Furst dkk. (2008); D’Emilio dkk. (2006); D’Emilio dkk. (2008).

Beberapa bagian dari bulir magnetic mengalami proses penghancuran secara perlahan akibat residu pestisida yang berasosiasi dengan bulir. Semakin lama bulir semakin menghalus dengan bertambahnya bulir-bulir halus (SP) mengakibatkan nilai FDS akan meningkat.

Pada gambar 2 diperlihatkan bahwa semakin lama pestisida tersimpan di dalam tanah dan seiring dengan meningkatnya konsentrasi pestisida proses disolusi pada tanah akan berlangsung lebih cepat dan progressive [6] dan penambahan bulir-bulir SP pun meningkat.. Proses pengayaan SP yang terjadi pada vuklanik soil akan meningkatkan nilai FDS.

Untuk menguatkan dugaan tentang proses disolusi yang terjadi pada tanah vulkanik maka telah dilakukan observasi SEM-EDX.

Gambar 3 adalah hasil visualisasi bulir magnetic yang terdapat pada topmost layer (Horizon 1). Gambar tersebut menunjukan kelimpahan bulir-bulir magnetik yang berbentuk bitetrahedral iron oxide yang berasosiasi dengan titanium, hal ini biasanya merupakan ciri dari tanah yang berasal dari daerah vulkanik [7]. Bulir-bulir magnetik yang diperoleh dari sampel yang belum terkontaminasi pestisida umumnya memperlihatkan bentuk-bentuk Kristal dengan permukaan yang masih mulus (Gambar 3A). Sementara bulir-bulir yg berasal dari sampel yang sudah terkontaminasi dengan pestisida umumnya memiliki permukaan yang mulai rusak (Gambar 3B). Diduga bulir magnetic pada sampel ini mulai mengalami proses disolusi [6]. Penambahan konsentrasi pestisida diduga mengakibatkan semakin progresivenya proses disolusi yaitu mulai melarutkan mineral-mineral magnetic terutama magnetite. Hal ini berakibat pada meningkatnya bulir-bulir yang lebih halus pada sampel tersebut sehingga proses identifikasi bulir secara visual menjadi lebih sulit karena bulir-bulir tersebut cenderung tercover di dalam matriks clay maupun silica (Gambar 3C). Kondisi yang ditemukan pada gambar 3C bersesuaian dengan analisis FDS yang menunjukan bahwa nilai FDS semakin meningkat pada sampel A16.

Hasil observasi SEM pada lapisan vulkanik ash layer (horizon 2) menunjukan morfologi dan kondisi bulir yang agak berbeda dengan horizon 1. Pada lapisan ini cenderung mudah menemukan bulir-bulir berbentuk batang dan berongga yang merupakan ciri dari hasil aktivitas vulkanik. Namun demikian, bulir-bulir magnetic berbentuk kristalin tetap mudah ditemukan. Gambar 4 memperlihatkan morfologi bulir magnetic yang ditemukan pada lapisan vulkanik ash layer. Pada lapisan ini, kondisi bulir magnetic dalam kaitannya dengan pengaruh pestisida menunjukkan hal yang sama dengan kondisi bulir magnetic pada sampel yang berasal dari horizon 1. Sampel yang sudah ditambahkan pestisida selama 3 bulan memperlihatkan bulir yang mulai merusak dan menghalus karena efek disolusi (Gambar 4b). Hal unik pada sampel yang berasal dari horizon 2 adalah ditemukannya bulir-bulir magnetic halus yang menempel pada bulir-bulir magnetic relative besar yang terlihat merusak. Hal ini terutama terjadi pada sampel yang sudah ditambahkan pestisida (Gambar 4B dan 4C). Bulir-bulir magnetic halus tersebut diduga merupakan hasil dari proses penumbuhan mineral magnetic. Jadi dapat dikatakan bahwa pengaruh penambahan pestisida pada horizon 2 tidak hanya mengakibatkan perusakan/pelarutan mineral magnetic tetapi juga disertai dengan tumbuhnya mineral-mineral magnetic yang baru. Kehadiran mineral magnetic berbulir halus sebagai hasil dari proses pertumbuhan kemungkinan dapat menjadi alasan lain mengapa nilai FDS pada sampel-sampel meningkat seiring dengan waktu penyimpanan. 

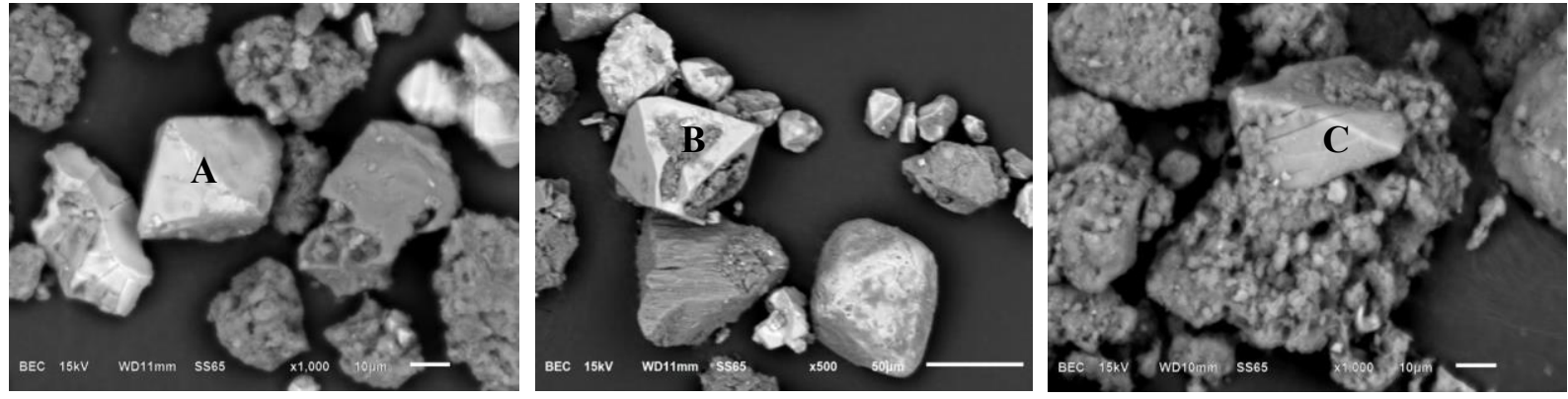

GAMBAR 1. Morfologi bulir dari tanah vulkanik pada lapisan pertama: (A) vulkanik soil alamiah (A10), (B) vulkanik soil setelah 3 bulan penambahan pestisida (A13), (C) Vulkanik Soil setelah 6 bulan penambahan pestisida (A16)
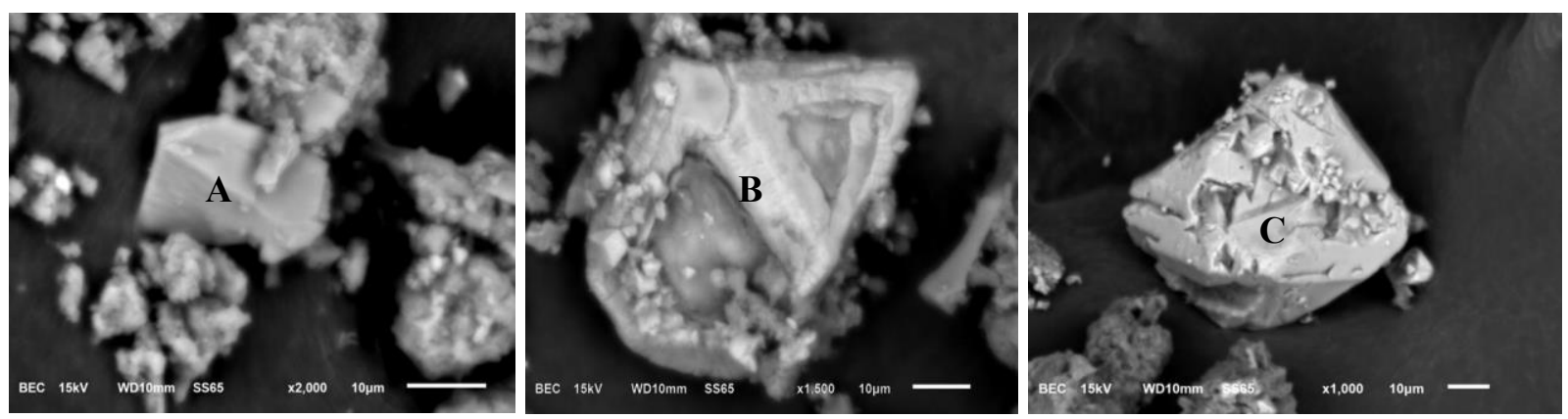

GAMBAR 2. Morfologi bulir dari tanah vulkanik pada lapisan kedua: (A) vulkanik soil alamiah (A20), (B) vulkanik soil setelah 3 penambahan pestisida (A23), (C) vulkanik soil setelah 6 bulan penambahan pestisida (A26)

Dari hasil analisis SEM menunjukan bahwa semakin lama dan semakin tinggi konsentrasi pestisida akan menyebabkan proses disolusi berjalan progressif dan pengayaan bulier SP semakin cepat. Kemungkinan hal ini menyebabkan nilai FDS meningkat.

\section{KESIMPULAN}

Dari hasil pengukuran magnetic diperoleh nilai FDS semakin meningkat seiring bertambahnya waktu pengamatan dan jumlah konsentrasi dari pestisida. Peningkatkan nilai FDS ini diduga sebagai efek dari pengayaan bulir SP pada sampel akibat proses disolusi yang disertai dengan penumbuhan mineral magnetic halus.

\section{UCAPAN TERIMA KASIH}

Departemen Pendidikan dan Kebudayaan Republik Indonesia yang telah memberikan beasiswa BPPS untuk EA dan GT. Riset ini juga disupport juga oelh riset grand dari ITB untuk SB melalui Hibah Penguatan Institusi. Kami juga berterima kasih pada PTPN VIII yg telah mengizinkan areanya menjadi tempat riset kami dan tak lupa pada bapak U. Samsuddin yang telah membantu selama proses pengambilan sampel. 


\section{DAFTAR PUSTAKA}

[1] D. Byrne, Primefacts, 316, 1-4 (2007)

[2] A.G. Jiries, F.M Al Nasir, F. Beese, Water Air Soil Poll 133: 97-107 (2002)

[3] R. Thompson and R. Oldfield. Environ. Magn. 277, (1986)

[4] J. A. Dearing, P. M. Bird, R. J. L. Dann, and S. F. Benjamin, Geophys. J. Int. 130, 727-736 (1997).

[5] M. J. Dekkers, Geol. Mijnbow 76, 163-182 (1997).

[6] B. A. Maher and R. Thompson, Quartenary Climates, Environments and Magnetism, UK, Cambridge Univ. Press (1999), pp 43.

[7] G.Tamuntuan, S.Bijaksana, E.Gaffar, J.Russell, L.O. Safiuddin, E. Huliselan, ITB J.Sci. 42A (1), 31-48 (2010) 
